\title{
EFFECT OF BENTONITE DOSAGE ON SHEAR BEHAVIOUR OF SAND-FLY ASH
}

\author{
Mahdi Keramatikerman \\ Engineer, Arup Australia, 61-73 Sturt Street, \\ Suncorp Tower, Townsville QLD 4810, Australia \\ Amin Chegenizadeh \\ Senior Lecturer, Department of Civil Engineering, \\ Curtin University of Technology, Kent Street, Bentley, Perth, Western Australia 6102, Australia \\ Hamid Nikraz \\ Professor, Department of Civil Engineering, \\ Curtin University of Technology, Kent Street, Bentley, Perth, Western Australia 6102, Australia
}

\begin{abstract}
Bentonite addition to soil sometime will be dealt as stabilisation. Shear behaviour of soil always has a great importance on engineering design. This study considers direct shear test on mixture of sand-flyash-bentonite. The direct shear device was employed with shear rate of 0.3 $\mathrm{mm} / \mathrm{min}$ and peak shear stress at failure of each specimen were recorded. The normal stress was applied as $150 \mathrm{kPa}$, $250 \mathrm{kPa}$, and $500 \mathrm{kPa}$. Addition of bentonite caused decreasing in peak shear.
\end{abstract}

Keywords - Shear, Flyash, Bentonite

\section{INTRODUCTION}

Sand is one of the main type of soils which has been in direct attention of researchers due to its abundant existence in various sites [1-4]. Application of mining waste is of interest due to the help to remove waste from landfill and at the same time putting it into soil to get benefit out of this. In general, additives have specific role in making soil stable [5-9]. There are examples in literature fibre, geo-grid, tire, lime, fly ash or agricultural waste [10-18]. Apart from experimental testing, numerical modelling also been conducted on pavement application of those materials [20-23]. In addition, sometime the issue is relevant to contamination which can be seen in [24-28] or effect of directional issue [29-33]. As can be seen the interest of usage of other materials [34-37]. Bentonite is also one of the most applicable types of soil in the industry [38-42]. Bentonite is an expansive type of clay [42-49]. This study focuses on how Portland cement would affect the performance of fly ash by itself as a soil replacement.

\section{MATERIALS}

The employed materials can be listed as:

The characteristics of fly ash can be found in the table below. The major component of used fly ash is $\mathrm{SiO} 2$ and $\mathrm{Al}_{2} \mathrm{O}_{3}$. Silicon dioxide $\left(\mathrm{SiO}_{2}\right) 51.8 \%$, Aluminum oxide $\left(\mathrm{Al}_{2} \mathrm{O}_{3}\right)$ $26.40 \%$, Ferric oxide $\left(\mathrm{Fe}_{2} \mathrm{O}_{3}\right) 13 \%$. The sand which was used in this study referred as yellow sand. The SG was 2.65. The medina size of particle was $1.2 \mathrm{~mm}$. The bentonite was expansive, and the median size was $36 \mu \mathrm{m}$.

\section{COMPACTION TESTING}

In the first stage, the compaction values were derived. The results of compaction can be seen in the Table 1:

Table 1. Results of OMD and MDD

\begin{tabular}{ccc}
\hline Sample ID & Bentonite & OMC \% \\
\hline S-F2 & 3 & 15 \\
S-F2 & 5 & 16.2 \\
S-F2 & 7 & 19 \\
S-F2 & 10 & 20.4
\end{tabular}


International Journal of Engineering Applied Sciences and Technology, 2020

Vol. 4, Issue 11, ISSN No. 2455-2143, Pages 63-66

Published Online March 2020 in IJEAST (http://www.ijeast.com)

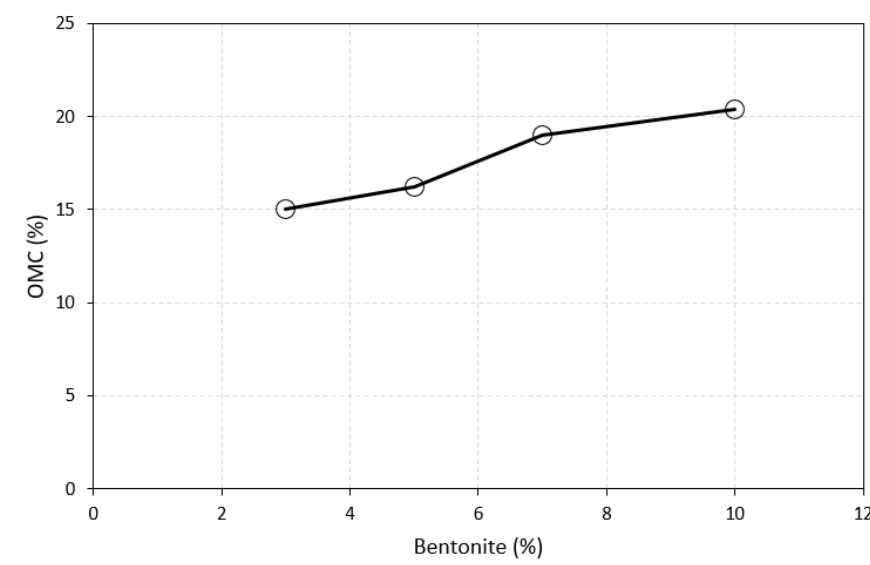

Fig. 1. OMC values of tested samples

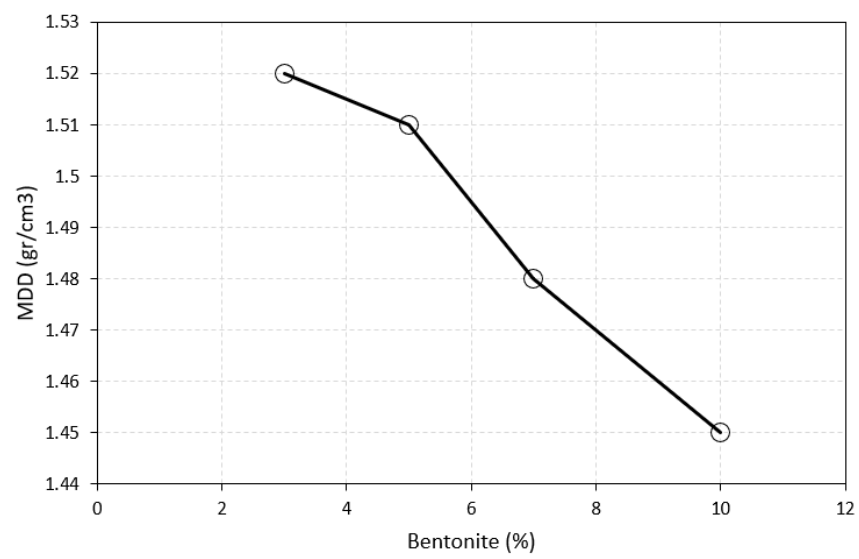

Fig. 2. MDD values of tested samples

\section{IV. $\quad$ SHEAR TESTS}

Direct shear test run with $0.3 \mathrm{~mm} / \mathrm{min}$. The sample were prepared in accordance with OMC and MDD of mixes. The results of peak shear stress at failure relevant to $150 \mathrm{kPa}$ with can be seen in the following figure. The below Fig. 3 is related to $150 \mathrm{kPa}$ shear at failure.

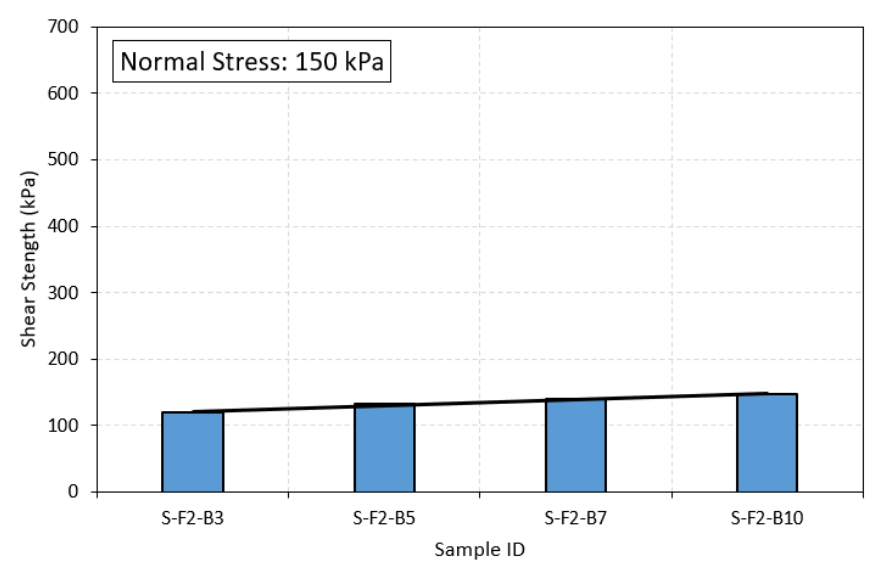

Fig. 3. Peak shear strength tested under $150 \mathrm{kPa}$ normal stress

The below Fig. 4 is related to $250 \mathrm{kPa}$ shear at failure.

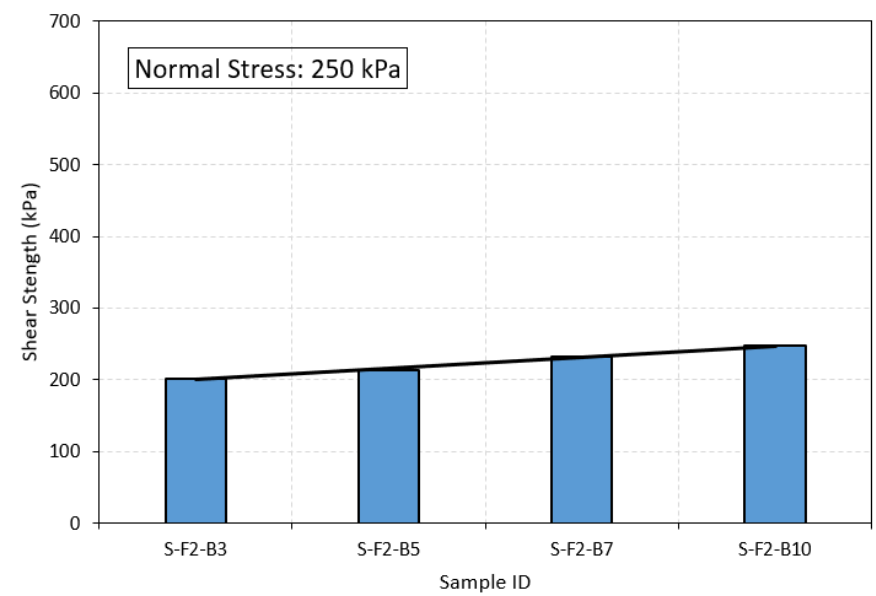

Fig. 4. Peak shear strength tested under $250 \mathrm{kPa}$ normal stress

The below Fig. 5 is related to $500 \mathrm{kPa}$ shear stress at failure for different specimen. 


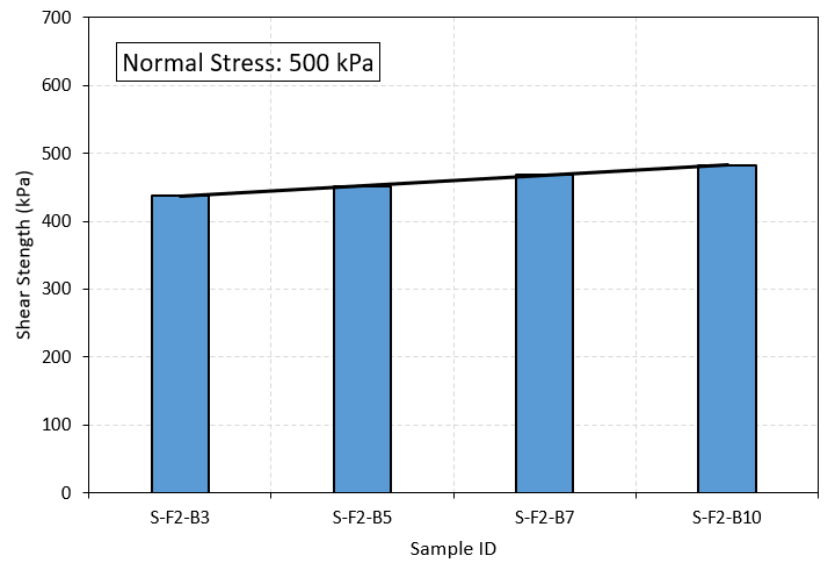

Fig. 5. Peak shear strength tested under 500 kPa normal stress

\section{CONCLUSION}

A series of shear and compaction test were conducted on the mixes and the result proved that bentonite increased the shear stress at failure. Compaction results showed the OMC increased by addition of bentonite and MDD increased at the same time.

\section{REFERENCE}

[1] Chegenizadeh, A., Nikraz, H. (2011a). "Investigation on strength of fiber reinforced clay" Advanced Materials Research 261-263, pp. 957-963.

[2] Mollins, L. H., Stewart, D. I., \& Cousens, T. W. (1996). Predicting the properties of bentonite-sand mixtures. Clay Minerals, 31(2), 243-252.

[3] Chegenizadeh, A. and H. Nikraz, (2011b). "Study on modulus of elasticity of reinforced clay" - Advanced Materials Research. 243-249: pp. 5885-5889, 2011.

[4] Komine, H., \& Ogata, N. (1999). Experimental study on swelling characteristics of sand-bentonite mixture for nuclear waste disposal. Soils and foundations, 39(2), 8397.

[5] Chegenizadeh, A. and H. Nikraz, (2011c). Composite Soil: Fiber Inclusion and Strength, Journal of Advanced Materials Research 1646

[6] Komine, H. (2004). Simplified evaluation on hydraulic conductivities of sand-bentonite mixture backfill. Applied clay science, 26(1-4), 13-19.

[7] Chegenizadeh, A. and H. Nikraz, (2012). Composite Clayey Sand and Short Fiber, Advanced Materials Research 383, 2764-2769

[8] Sun, D. A., Cui, H., \& Sun, W. (2009). Swelling of compacted sand-bentonite mixtures. Applied Clay Science, 43(3-4), 485-492.

[9] Chegenizadeh, A., Keramatikerman, M., \& Nikraz, H. (2018b). Liquefaction resistance of fibre reinforced lowplasticity silt. Soil Dynamics and Earthquake Engineering, 104, 372-377.
[10] Alawaji, H. A. (1999). Swell and compressibility characteristics of sand-bentonite mixtures inundated with liquids. Applied Clay Science, 15(3-4), 411-430.

[11] Al-Rkaby AHJ, Chegenizadeh A, Nikraz H. (2017). Anisotropic strength of large scale geogrid-reinforced sand:experimental study Soils and foundations 57 (4), 557-574

[12] Chegenizadeh A, Keramatikerman M, Panizza S, Nikraz H. (2017). Effect of powdered recycled tire on sulfate resistance of cemented clay. Journal of Materials in Civil Engineering. 2017 Oct 1;29(10):04017160.

[13] Abichou, T., Benson, C. H., \& Edil, T. B. (2002). Micro-structure and hydraulic conductivity of simulated sand-bentonite mixtures. Clays and Clay Minerals, 50(5), 537-545.

[14] Chegenizadeh, A., Keramatikerman, M., Dalla Santa, G., \& Nikraz, H. (2018a). Influence of recycled tyre amendment on the mechanical behaviour of soilbentonite cut-off walls. Journal of cleaner production, 177, 507-515.

[15] Mikhail, M., Chegenizadeh, A., Keramatikerman, M., Burns, G., Terzaghi, S., Nikraz, H. (2020). Application of Cane Ash on Compressive Strength of Soil Uncovered to $\mathrm{MgSO}_{4}$. International Journal of Engineering and Advanced Technology (IJEAT) 9(4).

[16] Amiralian S, Chegenizadeh A, Nikraz H (2012a) Laboratory investigation on the compaction properties of lime and fly ash composite, Proceedings of the International Conference on Civil and Architectural applications (ICCAA'2012) 79-83

[17] Lingnau, B. E., Graham, J., \& Tanaka, N. (1995). Isothermal modeling of sand-bentonite mixtures at elevated temperatures. Canadian Geotechnical Journal, 32(1), 78-88.

[18] Amiralian S, Chegenizadeh A, Nikraz H (2012b) Laboratory investigation on the effect of lime on compressibility of soil, Proceedings of the International Conference on Civil and Architectural applications (ICCAA'2012) 89-93

[19] Chalermyanont, T., \& Arrykul, S. (2005). Compacted sand-bentonite mixtures for hydraulic containment liners. Songklanakarin J. Sci. Technol, 27(2), 313-323.

[20] Sällfors, G., \& Öberg-Högsta, A. L. (2002). Determination of hydraulic conductivity of sandbentonite mixtures for engineering purposes. Geotechnical \& Geological Engineering, 20(1), 65-80.

[21] Keramatikerman, M., Chegenizadeh, A., Yilmaz, Y., \& Nikraz, H. (2018b). Effect of Lime Treatment on Static Liquefaction Behavior of Sand-Bentonite Mixtures. Journal of Materials in Civil Engineering, 30(11), 06018017.

[22] Abichou, T., Benson, C. H., \& Edil, T. B. (2004). Network model for hydraulic conductivity of sandbentonite mixtures. Canadian Geotechnical Journal, 41(4), 698-712. 


\section{International Journal of Engineering Applied Sciences and Technology, 2020 Vol. 4, Issue 11, ISSN No. 2455-2143, Pages 63-66 \\ Published Online March 2020 in IJEAST (http://www.ijeast.com)}

[23] Keramatikerman, M., Chegenizadeh, A., \& Nikraz, H. (2018). Effect of Flyash on Post-Cyclic Behavior of Sand. Journal of Earthquake Engineering, 1-13.

[24] Chalermyanont, T., \& Arrykul, S. (2005). Compacted sand-bentonite mixtures for hydraulic containment liners. Songklanakarin J. Sci. Technol, 27(2), 313-323.

[25] Keramatikerman, M., Chegenizadeh, A., Nikraz, H., \& Sabbar, A. S. (2018a). Effect of flyash on liquefaction behaviour of sand-bentonite mixture. Soils and foundations, 58(5), 1288-1296.

[26] Gueddouda, M. K., Lamara, M., Aboubaker, N., \& Taibi, S. (2008). Hydraulic conductivity and shear strength of dune sand-bentonite mixtures. Electronic Journal of Geotechnical Engineering, 13, 1-15.

[27] Keramatikerman M, Chegenizadeh A, Nikraz H. (2017b). Experimental study on effect of flyash on liquefaction resistance of sand Soil Dynamics and Earthquake Engineering 93, 1-6

[28] Graham, J., Saadat, F., Gray, M. N., Dixon, D. A., \& Zhang, Q. Y. (1989). Strength and volume change behaviour of a sand-bentonite mixture. Canadian Geotechnical Journal, 26(2), 292-305.

[29] Chegenizadeh, A., \& Keramatikerman, M. (2017). Mitigating sulphate attacks in geotechnical engineering Hauppauge, New York, USA Nova Science Publishers. (pp. 1-165).

[30] Jewell, R. A., \& Wroth, C. P. (1987). Direct shear tests on reinforced sand. Geotechnique, 37(1), 53-68.

[31] Chegenizadeh, A., Keramatikerman, M., Miceli, S., Nikraz, H., Salih Sabbar, A. (2020). Investigation on Recycled Sawdust in Controlling Sulphate Attack in Cemented Clay. Appl. Sci., 10, 1441.

[32] Jewell, R. A. (1989). Direct shear tests on sand. Geotechnique, 39(2), 309-322.

[33] Keramatikerman, M., Chegenizadeh, A., \& Nikraz, H. $(2017 \mathrm{c})$. An investigation into effect of sawdust treatment on permeability and compressibility of soilbentonite slurry cut-off wall. Journal of Cleaner Production, 162, 1-6.

[34] Lings, M. L., \& Dietz, M. S. (2004). An improved direct shear apparatus for sand. Geotechnique, 54(4), 245-256.

[35] Keramatikerman M, Chegenizadeh A, Terzaghi S. (2019) Review on Effect of Sugarcane Bagasse Ash as an Additive in Construction Industry. 2019. EJGE. Vol.24 Bun. 02.

[36] Shewbridge, S. E., \& Sitar, N. (1989). Deformation characteristics of reinforced sand in direct shear. Journal of geotechnical engineering, 115(8), 1134-1147.

[37] Chegenizadeh, A., Keramatikerman, M., \& Nikraz, H. (2016). Flexible pavement modelling using Kenlayer. EJGE, 21, 2467-2479.

[38] Keramatikerman, M., Chegenizadeh, A., \& Pu, H. (2017a). Effect of atrazine contamination on compressibility and permeability characteristics of clay. Geotechnical Testing Journal, 40(6), 936-950.

[39] Al-Rkaby AHJ, Chegenizadeh A, Nikraz H. (2016). Directional-dependence in the mechanical characteristics of sand: A Review International Journal of Geotechnical Engineering 10 (5), 499-509

[40] Chegenizadeh, A., Keramatikerman, M., Nikraz, H., Importance of Microstructural Analysis in Experimental Soil Stabilization. Global Journal of Engineering Science. 4(5): 2020.

[41] Chegenizadeh A, Aashish M, Nikraz H, Keramatikerman M. Sulphate Attack on CementedBentonite-Coconut Coir. Results in Engineering. 2020 Mar 3:100111.

[42] Keramatikerman M, Chegenizadeh A, Nikraz H. Effect of Slag on Restoration Mechanical Characteristics of Ethanol Gasoline-Contaminated Clay. Journal of Environmental Engineering. 2018 Jul 1;144(7):06018001.

[43] Keramatikerman M, Chegenizadeh A, Nikraz H. Shear strength characteristics of over-consolidated clay treated with ggbfs. Australian Geomechanics Journal. 2018;53(2):141-9.

[44] Keramatikerman, M. (2018). Investigations into Effect of By-product Binders in Improvement of Cyclic Behaviour of Soil (Doctoral dissertation, Curtin University).

[45] Keramatikerman, M., Chegenizadeh, A., Nikraz, H. How Ground Improvement Addresses the United Nation Sustainable Development Goals: A Review. Current Trends in Civil \& Structural Engineering 5(3): 2020. CTCSE.MS.ID.000613.

DOI: 10.33552/CTCSE.2020.05.000613

[46] Mikhail, M., Keramatikerman, M., Chegenizadeh, A., Terzaghi, S., Burns, G., Nikraz, H. (2020). Influence of Bagasse Ash on Compaction Behvaiour of Soil. International Journal of Innovative Technology and Exploring Engineering (IJITEE). 9(5).

[47] Keramatikerman M, Chegenizadeh A, Nikraz H. Effect of sawdust on Cohesion of Sand-Sawdust mixture. International Journal of Engineering Applied Sciences and Technology (IJEAST), 2020 (accepted).

[48] Keramatikerman M, Chegenizadeh A, Nikraz H. SOIL STABILISATION USING GLASS POWDER. International Journal of Engineering Applied Sciences and Technology (IJEAST), 2020 (accepted)

[49] Keramatikerman M, Chegenizadeh A, Nikraz H. STRENGTH OF CEMENTED FLY ASH SOIL. International Journal of Engineering Applied Sciences and Technology (IJEAST), 2020 (accepted). 